\title{
DINAMIKA SERANGAN ULAT Heortia vitessoides MOORE (LEPIDOPTERA: CRAMBIDAE) PADA TANAMAN GAHARU DI HUTAN PENELITIAN CARITA, PROPINSI BANTEN
}

\author{
Dynamic Infestation of Herbivorous Caterpillar of Heortia vitessoides Moore (Lepidoptera: \\ Crambidae) on Agarwood Plantation in Carita Forest Research Station, Province of Banten
}

Kuntadi, Ragil S.B. Irianto dan/and Lincah Andadari

Pusat Penelitian dan Pengembangan Hutan

Jl. Gunung Batu No. 5 Kotak Pos 165 Bogor 16118, Jawa Barat, Indonesia

Tlp. : (0251) 8633234; Fax. : (0251) 8638111

Email : kuntadi10@yahoo.com; ragil.irianto@gmail.com; a.lincah@yahoo.co.id

Tanggal diterima : 24 Juni 2016; Tanggal direvisi : 5 September 2016; Tanggal disetujui : 5 Desember 2016

\begin{abstract}
Heortia vitessoides Moore is the most serious pest on agarwood trees for causing defoliation. A three years survey was conducted at Carita Forest Research Station, Banten Province, to describe the pattern and dynamic of pest infestation. Monthly monitoring were done at 3 permanent plots, each representing planting block of agarwood with different ecological and stand conditions. Each plot contained six subplots and each subplot consisted of 15 agarwood trees. The presence of pests, the level of infestation, and the attacking frequency were recorded. The results showed that pests occurred throughout the year with attack patterns fluctuated. The highest infestation occurred during dry season. The pest was mostly found as one colony of gregarious caterpillars in various instar. Most of the agarwood trees had recurrent attacks with a frequency of 2-3 times per year. The intensity of attack tend to be higher in the seedling of agarwood trees grown in open areas with lower density of shrubs and vegetation.
\end{abstract}

Key words: Agarwood trees, dynamics, frequency, intensity, pest

\begin{abstract}
ABSTRAK
Heortia vitessoides Moore adalah jenis rama-rama dari famili Crambidae. Larva serangga ini merupakan hama paling serius pada tanaman gaharu karena menyebabkan penggundulan daun. Penelitian ini bertujuan mengetahui pola dan dinamika serangan ulat $H$. vitessoides pada tanaman gaharu. Penelitian dilakukan selama 3 tahun di Hutan Penelitian Carita, Propinsi Banten, dengan melakukan monitoring berkala di 3 plot pengamatan permanen yang masing-masing mewakili blok penanaman gaharu dengan kondisi ekologis dan ukuran tegakan berbeda. Pada setiap plot penelitian terdapat 6 sub plot dan setiap sub plot terdiri dari 15 tanaman gaharu yang rutin diamati. Data yang dikumpulkan, yaitu keberadaan hama (meliputi stadia dan populasi hama), tingkat serangan dan frekuensi serangan hama yang dicatat setiap bulan. Hasil penelitian menunjukkan serangan hama terjadi sepanjang tahun dengan pola serangan berfluktuasi. Serangan tertinggi terjadi pada musim kemarau. Pada setiap pohon yang terserang rata-rata hanya ditemukan satu koloni ulat gaharu dalam berbagai instar. Sebagian besar tanaman gaharu mengalami serangan berulang dengan frekuensi 2-3 kali per tahun. Intensitas serangan cenderung lebih tinggi pada tingkat seedling dan pada pertanaman gaharu di lokasi terbuka dengan tingkat kerapatan vegetasi dan tumbuhan bawah yang semakin rendah.
\end{abstract}

Kata kunci: Dinamika, frekuensi, hama, intensitas, tanaman gaharu 


\section{PENDAHULUAN}

Ulat gaharu adalah hama yang paling berbahaya bagi tanaman gaharu (Aquilaria sp.; Gyrinops sp.) saat ini. Ulat gaharu merupakan larva Heortia vitessoides Moore, sejenis ngengat atau rama-rama dari keluarga Crambidae. Wilayah sebaran serangga ini meliputi India, Nepal, China, Sri Langka, seluruh wilayah Asia Tenggara, Queensland (Australia), hingga Fiji (Qiao et al., 2012; Saikia \& Shrivastava, 2015).

Serangan ulat $H$. vitessoides telah mengakibatkan kerusakan dan kematian tanaman gaharu di berbagai daerah di Indonesia. Dimulai dari India pada tahun 1998, serangan berat hama gaharu di Indonesia mulai terjadi sejak tahun 2005. Secara beruntun, serangan hama $H$. vitessoides dilaporkan terjadi di Sanggau (Kalimantan Barat) tahun 2007, Carita (Banten) tahun 2008, Bogor (Jawa Barat) tahun 2009, Mataram (NTB) tahun 2009 (Irianto et al., 2011). Saat ini serangan hama gaharu telah menyebar ke berbagai daerah di Sumatera, Kalimatan, Jawa, Bali hingga pulau Lombok di kepulauan Nusa Tenggara.

Ngengat betina dewasa bertelur di bawah permukaan daun yang masih muda dan diletakkan secara berkelompok. Massa telur berwarna kekuningan dalam jumlah yang sangat banyak, berkisar antara 100-550 butir (Agustina, 2012; Emilia, 2013). Telur menetas dalam waktu 1 minggu setelah dikeluarkan (oviposition) menjadi ulat-ulat kecil berukuran sekitar $2 \mathrm{~mm}$. Stadia larva berlangsung selama 23 hari dan larva tumbuh melalui 5 tahap perkembangan (instar) hingga mencapai panjang rata-rata $30 \mathrm{~mm}$ pada instar terakhir. Selama masa awal perkembangan ulat gaharu beragregasi dan hidup dari memakan bagian kloropil daun yang muda. Larva dewasa menyebar ke seluruh cabang tanaman yang mampu dijangkau dan aktif memangsa semua bagian daun.

Ulat gaharu termasuk golongan serangga herbivora yang hanya makan jenis tumbuhan tertentu (oligophagous) (Qiao et al., 2012). Selain memangsa daun gaharu, ulat $H$. vitessoides juga menyerang kerabat terdekat pohon gaharu sesama famili Thymeleaeceae yaitu mahkota dewa (Phaleria sp.) (Hariri \& Indriyati, 2011; Agustina, 2012; Hariri, 2012; Emilia, 2013; Mohd Masri et al., 2014; Saikia \& Shrivastava, 2015). Hama ini memangsa daun dan kulit ranting dan menyebabkan terjadinya penggundulan (complete defoliation) pada semua jenis dan berbagai tingkat umur pohon gaharu. Dalam satu tahun hama H. vitessoides dapat berkembang dalam 7-8 generasi, sehingga serangan yang berulang tidak hanya beresiko menghambat pertumbuhan tanaman tetapi juga menyebabkan kematian (Qiao et al., 2012; Lestari \& Suryanto, 2012; Lestari \& Darwiati, 2014).

Tindakan pengendalian diperlukan untuk mencegah semakin berkembangnya hama gaharu. Pengendalian hama pada dasarnya adalah upaya pengaturan atau pengelolaan suatu spesies yang dinyatakan sebagai hama, karena dianggap membahayakan bagi kesehatan manusia dan/atau merugikan bagi lingkungan dan perekonomian. Pengelolaan hama adalah suatu pilihan dan tindakan pengendalian suatu spesies hama yang dilakukan dengan memperhitungan konsekuensinya secara ekonomis, ekologis dan sosiologis (Dhawan \& Peshin, 2009). Oleh sebab itu, secara taktis monitoring serangan hama adalah salah satu langkah penting dalam tahapan atau proses pengendalian suatu hama (Orr, 2009). Monitoring serangan hama diperlukan untuk menentukan kapan pola kehidupan suatu spesies hama perlu dimodifikasi untuk mengurangi jumlah atau populasinya pada tingkat yang dapat ditolerir (di bawah ambang batas ekonomi).

Penelitian dinamika populasi dan serangan hama ulat $H$. vitessoides dimaksudkan untuk mengetahui perkembangan populasi dan pola serangan hama gaharu di alam. Dengan penelitian ini diharapkan dapat diperoleh informasi kapan perlu dilakukan tindakan pengendalian serangan hama yang efisien dan efektif untuk mengurangi jumlah atau populasinya.

\section{METODOLOGI}

\section{A. Waktu dan Lokasi}

Penelitian dilakukan selama 3 tahun, mulai bulan April 2012 sampai dengan Maret 2015, di Hutan Penelitian (HP) Carita. HP Carita merupakan Kawasan Hutan Dengan Tujuan Khusus (KHDTK) yang dikelola oleh Pusat Penelitian dan Pengembangan Hutan, Badan Litbang dan Inovasi Kementerian Lingkungan Hidup dan Kehutanan. HP Carita berada di wilayah Kecamatan Labuan, Kabupaten Pandeglang, Propinsi Banten. Mengutip Samsoedin et al. (2010), KHDTK Carita tergolong hutan pamah dengan keadaan topografi landai sampai curam $\left(0-35^{\circ}\right)$ dan tipe curah hujan sesuai klasifikasi Schmidt dan Ferguson adalah 
tipe A dengan curah hujan rata-rata tahunan sebesar $3.950 \mathrm{~mm}$. Suhu udara rata-rata antara $23-32^{\circ} \mathrm{C}$ dengan kelembaban udara antara 77 $85 \%$.

Hutan Penelitian Carita dipilih sebagai lokasi penelitian dinamika serangan ulat gaharu karena tersedianya beberapa blok tanaman gaharu yang relatif bervariasi, baik umur tanam maupun sistem pengelolaan lahannya. Variasi kondisi tanaman gaharu ini memungkinkan untuk melihat ada tidaknya keterkaitan antara variasi kondisi tegakan dan sistem pengelolaan lahan dengan dinamika populasi dan serangan hama gaharu. Gambar 1 memperlihatkan lokasi blok tanaman gaharu di KHDTK Carita, masingmasing yaitu :
- Blok gaharu I (werkit) seluas \pm 4 ha terletak pada petak 71 KHDTK Carita, sesuai dengan posisi lokasi yang berada di belakang kantor jaga atau werkit sebagai tanaman percontohan.

- Blok gaharu II (rorak) seluas \pm 2 ha terletak pada petak 75 KHDTK Carita, sesuai dengan tujuan penanaman dalam rangka kegiatan penelitian rorak.

- Blok gaharu III (ITTO) seluas \pm 10 ha terletak pada petak 69 KHDTK Carita, sesuai dengan tujuan penanaman dalam rangka pelaksanaan kegiatan pengembangan gaharu melalui proyek III PD425/06 Rev. 1 (I).

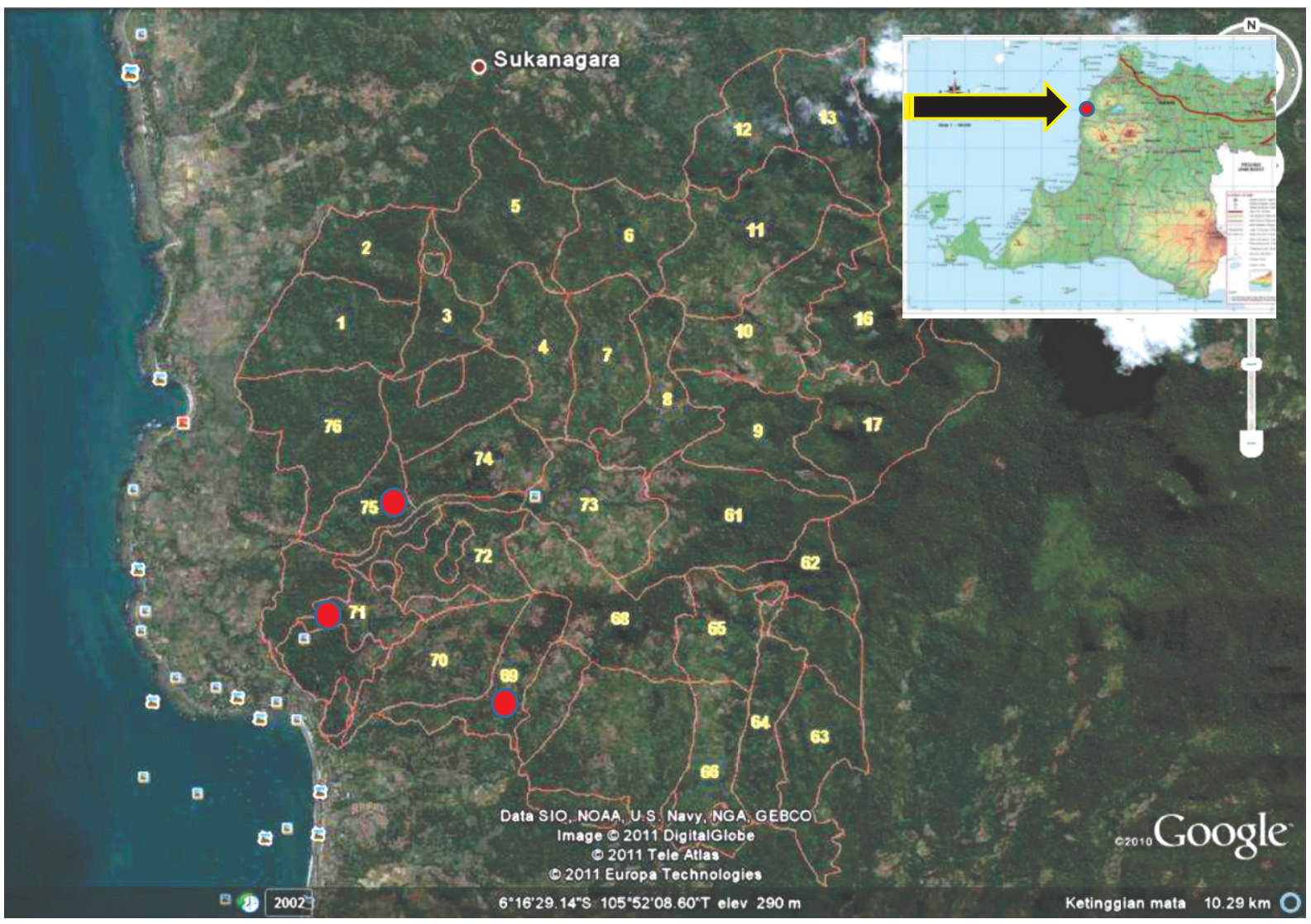

Sumber (Source) : Peta Google Earth (Source of Google Earth map): http://www.forda-mof.org/files/Puskonser_Carita.pdf

Gambar(Figure) 1. Lokasi blok pertanaman gaharu (titik merah) di Hutan Penelitian Carita (Plantation sites of agarwood (red dots) at Carita Forest Research Station) 


\section{B. Bahan dan Alat}

Bahan penelitian yang digunakan, yaitu tallysheet untuk mencatat data serangan ulat gaharu. Peralatan yang digunakan antara lain penanda identitas pohon contoh dan hand counter sebagai alat bantu pengukur jumlah populasi hama serta beberapa peralatan pendukung lainnya.

\section{Prosedur Kerja}

Penelitian dilakukan melalui observasi berkala setiap bulan terhadap kejadian serangan pada setiap pohon contoh tanaman gaharu. Pohon contoh, yaitu sejumlah tanaman gaharu yang ditentukan menjadi obyek pengamatan secara tetap selama proses penelitian. Untuk itu, prosedur kerja yang dilakukan meliputi, (1) pembuatan plot pengamatan permanen, (2) pengumpulan data dan (3) pengolahan dan analisis data.

\section{Plot pengamatan}

Dalam penelitian ini digunakan 3 plot pengamatan, masing-masing plot ditentukan secara purposive berdasarkan variasi blok umur tanaman dan kondisi ekologis tegakan gaharu yang ada di KHDTK Carita. Ketiga plot penelitian tersebut yaitu plot I (werkit), II (rorak) dan plot III ( ITTO). Pada setiap plot terdapat 6 sub plot dan setiap sub plot terdiri dari 15 tegakan tanaman gaharu. Setiap sub plot dan tanaman gaharu yang ada didalamnya ditentukan secara acak. Tabel 1 menjelaskan karakteristik masingmasing plot penelitian, baik kondisi tanaman gaharu maupun kondisi lingkungannya. Secara umum dapat dikatakan bahwa tanaman gaharu di plot I memiliki rata-rata tinggi dan diameter yang lebih besar dibandingkan 2 plot lainnya. Sementara tanaman gaharu di plot II dan III memiliki rata-rata tinggi dan dimeter batang yang relatif sama. Plot I juga memiliki kondisi lingkungan hutan dengan tingkat kerapatan pohon dan tumbuhan bawah yang jauh lebih tinggi dari 2 plot lainnya. Adapun tingkat kerapatan pohon hutan di plot II dan III relatif tidak jauh berbeda, namun plot II memiliki tingkat kerapatan tumbuhan bawah yang lebih tinggi daripada plot III. Dengan kata lain dapat dikatakan bahwa plot III memiliki kondisi lingkungan yang lebih terbuka.

Tabel (Table) 1. Karakteristik plot pengamatan (Characteristics of research plots)

\begin{tabular}{lccc}
\hline \multicolumn{1}{c}{$\begin{array}{c}\text { Karakteristik plot } \\
\text { (Plot characteristics) }\end{array}$} & I & II & III \\
\hline $\begin{array}{l}\text { Tahun tanam gaharu } \\
\text { (Planting year of agarwood) }\end{array}$ & 2004 & 2006 & 2008 \\
$\begin{array}{l}\text { Rata-rata tinggi pohon gaharu } \\
\text { Average height of agarwood trees) } \\
(\mathrm{cm})\end{array}$ & 400 & 102 & 112 \\
$\begin{array}{l}\text { Rata-rata diameter pohon gaharu } \\
\text { (Average diameter of agarwood } \\
\text { trees) (cm) }\end{array}$ & 3,9 & 2 & 1,8 \\
$\begin{array}{l}\text { Kerapatan tegakan hutan } \\
\text { (Forest stand density) (pohon per ha) }\end{array}$ & 6.875 & 5.550 & 5.675 \\
$\begin{array}{l}\text { Kerapatan tumbuhan bawah } \\
\text { (Shrub density) (batang per ha) }\end{array}$ & 12.950 & 9.700 & 6.625 \\
\hline
\end{tabular}




\section{Pengumpulan data}

Pengumpulan data dilakukan melalui pengamatan secara berkala setiap bulan. Data yang dikumpulkan yaitu tingkat kejadian serangan, keberadaan hama dan frekuensi serangan hama.

Tingkat kejadian serangan dihitung berdasarkan persen rata-rata jumlah pohon yang kedapatan terserang ulat gaharu di setiap plot pada bulan pengamatan tertentu. Selanjutnya, di setiap tanaman gaharu yang terserang dilakukan pengamatan keberadaan hama dengan mengamati stadia dan populasinya. Apabila hama masih dalam stadia telur dilakukan penghitungan jumlah kelompok telur di setiap pohon dan jumlah butir di setiap kelompok telur. Apabila hama dalam stadia ulat, dilakukan pengukuran panjang ulat untuk menentukan perkiraan instar ulat dan penghitungan populasi ulat dari setiap instar.

Frekuensi serangan hama dihitung berdasarkan jumlah kejadian serangan dalam satu tahun pada masing-masing pohon yang diamati.

Data iklim diperoleh dari Kantor Stasiun Meteorologi Kelas I Serang, berupa data bulanan curah hujan $(\mathrm{CH})$, jumlah hari hujan $(\mathrm{HH})$ dan kelembaban rata-rata. Data meteorologi tersebut merupakan hasil pengukuran di wilayah Kecamatan Labuan, yakni wilayah di Kab. Pandeglang yang terdekat dengan lokasi penelitian.

\section{Analisis Data}

Analisis data dilakukan secara statistik dan deskriptif. Analisis regresi dilakukan menggunakan program Minitab 16 untuk menguji hubungan antara intensitas serangan hama dengan beberapa faktor iklim, yakni curah hujan $(\mathrm{CH})$, jumlah hari hujan $(\mathrm{HH})$ dan kelembaban udara (RH). Selanjutnya dilakukan analisis secara deskriptif untuk menelaah data perkembangan tingkat kejadian dan pola serangan ulat gaharu di masing-masing plot pengamatan.

\section{HASIL DAN PEMBAHASAN}

\section{A. Hasil}

Serangan hama $H$. vitessoides pada tanaman gaharu di HP Carita, Propinsi Banten, terjadi sepanjang tahun dengan pola serangan berfluktuasi. Data pengamatan selama 3 tahun memperlihatkan serangan hama lebih banyak terjadi pada musim kemarau dibanding musim hujan (Gambar 2). Meskipun demikian, analisis regresi menunjukkan tidak terdapat korelasi $(\mathrm{P}>$ $0,05)$ antara persentase rata-rata jumlah pohon yang terserang hama dengan beberapa faktor iklim seperti curah hujan, jumlah hari hujan dan kelembaban udara.

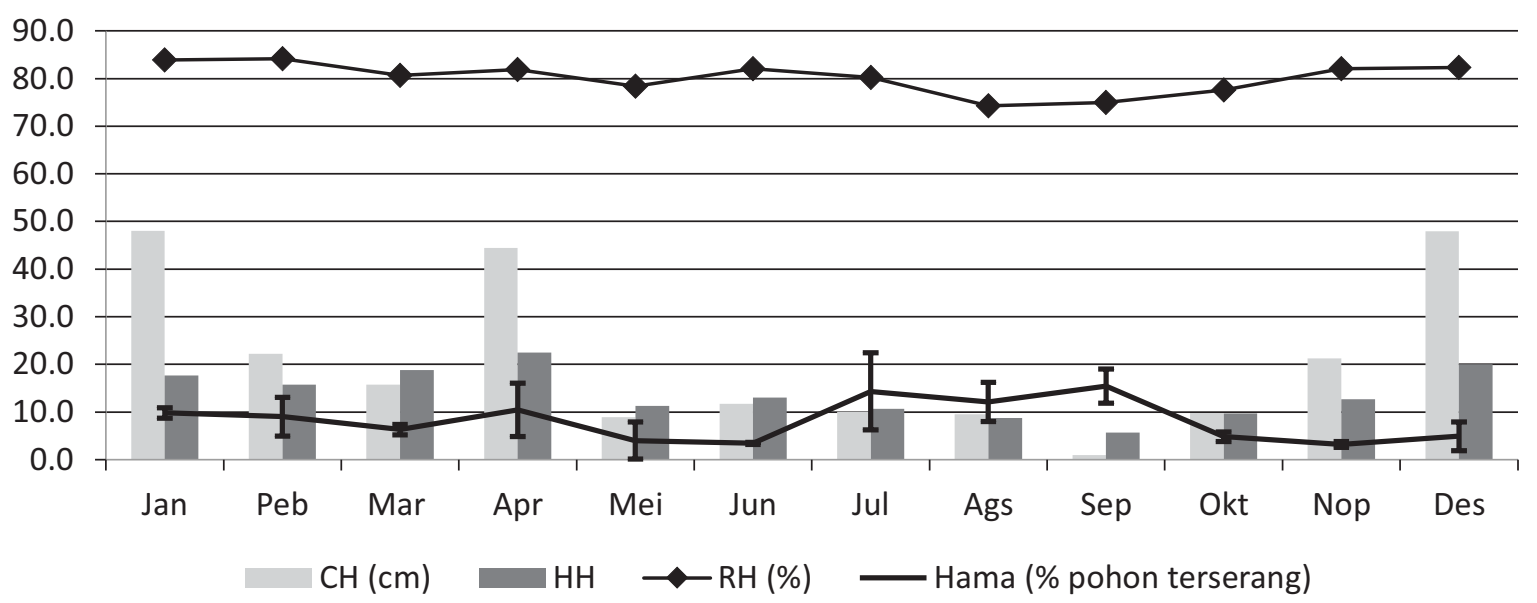

Gambar(Figure)2. Persentase jumlah pohon yang terserang hama di Hutan Penelitian Carita berikut jumlah hari hujan $(\mathrm{HH})$, curah hujan $(\mathrm{CH})$ dan kelembaban udara $(\mathrm{RH})$ bulanan di wilayah Kecamatan Labuan (The mean percentages of agarwood trees attacked by the pest in Carita Forest Research Station and the monthly numbers of rain days, daily precipitation and relative humidity in the area of Labuan Sub District) 
Persentase jumlah pohon terserang hama relatif stabil antara $5-10 \%$ pada awal tahun antara Januari-Mei, kemudian turun hingga titik terendah pada akhir musim hujan sekitar bulan Mei-Juni. Memasuki musim kemarau sekitar bulan Juli-September serangan hama meningkat dengan rata-rata persentase jumlah pohon yang terserang berkisar $13-17 \%$. Serangan hama turun kembali pada saat memasuki musim hujan pada bulan Oktober-Desember dengan persentase rata-rata jumlah pohon yang terserang di bawah $5 \%$.

Pengamatan pada masing-masing plot memperlihatkan tidak satu pun plot yang terbebas dari serangan hama. Hama $H$. vitessoides, baik dalam stadia telur maupun ulat berbagai instar, ditemukan di sebagian tanaman yang diamati di setiap plot di hampir sepanjang waktu pengamatan meskipun dengan tingkat kejadian serangan yang berbeda dari waktu ke waktu. Perkembangan populasi hama di ketiga plot pengamatan menunjukkan pola yang hampir sama, namun persentase pohon yang terserang hama sedikit lebih tinggi pada plot II dan III dari pada plot I (Gambar 3).

Hama ulat ditemukan dalam beberapa instar, namun umumnya instar 1 dan 2 . Pada setiap pohon yang terserang kebanyakan hanya terdapat satu macam instar. Dengan kata lain hanya ada satu generasi ulat gaharu pada setiap pohon yang terserang. Namun karena keberadaan hama hampir selalu ditemukan di setiap bulan pengamatan di semua plot, berarti dalam 1 tahun terdapat beberapa generasi perkembangan hama.

Jumlah populasi ulat yang ditemukan menyerang tanaman gaharu bervariasi sesuai instarnya. Pada instar awal (instar 1) umumnya masih dalam jumlah besar, berkisar antara 100200 individu. Pola serangan hama sangat tergantung dari instar ulat. Ulat yang baru menetas hingga instar 2 menyerang pohon gaharu secara berkelompok (agregasi) dengan memangsa daun yang masih muda. Pada instar berikutnya dengan ukuran tubuh yang lebih besar, serangan ulat sudah menyebar dengan sasaran semua daun yang masih tersedia.

Hasil mapping serangan ulat di keseluruhan pohon contoh menunjukkan sebagian besar pernah terserang ulat (Tabel 2). Hanya plot I yang persentase jumlah pohon yang tidak pernah terserang hama gaharu dalam 3 tahun pengamatan relatif masih cukup besar, yaitu ratarata $22,2 \%$. Pada plot II semua pohon contoh di 6 sub plot pengamatan permanen pernah mengalami serangan hama, kecuali pada tahun pertama (2012) terdapat 6,7\% tanaman gaharu yang bebas serangan. Demikian juga di plot III, hampir semua pohon contoh pernah terserang hama. Data tersebut menunjukkan bahwa intensitas serangan $H$. vitessoides di plot II dan III lebih tinggi dibanding plot I.

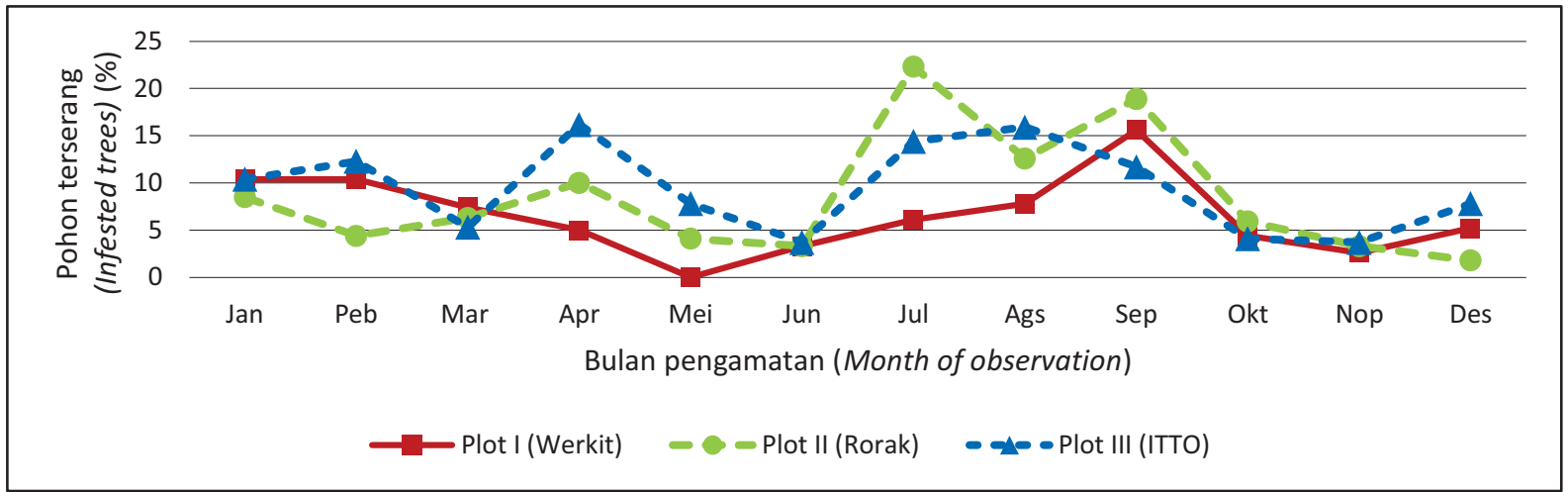

Gambar(Figure)3. Dinamika perkembangan hama pada pohon gaharu di plot pengamatan I, II dan III berdasarkan persentase populasi pohon yang terserang (Dynamic of pest infestation on agarwood plantation in observation plots of I, II and III based on the mean percentage of pest attacking trees) 
Tabel (Tabel) 2. Persentase jumlah pohon gaharu yang terserang H. vitessoides secara berulang dalam 1 tahun sesuai frekuensi serangan (Percentage of agarwood trees under recurrent attacks of $\underline{\mathrm{H}}$. vitessoides within a year according to its frequencies of attack).

\begin{tabular}{|c|c|c|c|c|c|c|c|c|c|c|c|c|}
\hline \multirow{3}{*}{$\begin{array}{c}\text { Frekuensi } \\
\text { serangan } \\
\text { (Attacking } \\
\text { frequencies) }\end{array}$} & \multicolumn{12}{|c|}{ Jumlah pohon (Number of trees) (\%) } \\
\hline & \multicolumn{4}{|c|}{ I } & \multicolumn{4}{|c|}{ II } & \multicolumn{4}{|c|}{ III } \\
\hline & 2012 & 2013 & 2014 & $X$ & 2012 & 2013 & 2014 & $\bar{X}$ & 2012 & 2013 & 2014 & $X$ \\
\hline 0 & 26,7 & 14,4 & 25,6 & 22,2 & 6,7 & 0,0 & 0,0 & 2,2 & 8,9 & 2,2 & 3,3 & 4,8 \\
\hline 1 & 46,7 & 36,7 & 37,8 & 40,4 & 60,0 & 8,9 & 21,1 & 30,0 & 38,9 & 11,1 & 13,3 & 21,1 \\
\hline 2 & 22,2 & 31,1 & 31,1 & 28,1 & 28,0 & 32,2 & 41,1 & 33,8 & 38,9 & 36,7 & 35,6 & $\mathbf{3 7 , 1}$ \\
\hline 3 & 4,4 & 17,8 & 2,2 & 8,1 & 2,2 & 41,1 & 33,3 & 25,5 & 13,3 & 32,2 & 36,7 & 27,4 \\
\hline 4 & 0,0 & 0,0 & 0,0 & $\mathbf{0 , 0}$ & 0,0 & 17,8 & 4,4 & 7,4 & 0,0 & 17,8 & 11,1 & 9,6 \\
\hline
\end{tabular}

Frekuensi serangan hama pada setiap pohon contoh berkisar 1-4 kali dalam satu tahun (Tabel 2). Serangan lebih dari satu kali pada individu pohon gaharu terjadi di semua plot pengamatan. Serangan berulang lebih banyak terjadi pada plot II dan III yang rata-rata tinggi pohonnya kurang dari 1,5 m. Di kedua plot, serangan berulang ulat $H$. vitessoides dalam 1 tahun tergolong sangat tinggi. Berdasarkan jumlah persentase rata-rata jumlah pohon yang terserang ulat lebih dari $1 \mathrm{kali}$ dalam 1 tahun $(\bar{X})$, serangan berulang (frekuensi serangan $\geq 2$ ) rata-rata dialami oleh lebih dari $65 \%$ jumlah individu pohon. Sementara di plot I dengan tinggi pohon rata-rata di atas $4 \mathrm{~m}$ serangan berulang hanya terjadi sekitar 36\% jumlah individu pohon. Serangan berulang dengan frekuensi 2 kali dalam 1 tahun relatif seimbang di ketiga plot pengamatan, yakni sebesar $28,1 \% ; 33,8 \%$ dan $37,1 \%$ berturut-turut pada plot I, II dan III. Serangan dengan frekuensi 3 kali setahun terutama terjadi di plot II dan III dengan persentase jumlah pohon terserang di atas 3 kali lebih besar dibandingkan yang terjadi di plot I. Rata-rata persentase jumlah pohon yang terserang hama 3 kali per tahun di plot I, II dan III berturut-turut yaitu $8,1 \% ; 25,5 \%$ dan $27,4 \%$. Serangan hama $H$. vitessoides dengan frekuensi 4 kali dalam 1 tahun pada 1 pohon gaharu hanya terjadi di plot II dan III. Data di atas menunjukkan bahwa plot II dan III lebih rentan terhadap serangan ulat gaharu daripada plot I.

\section{B. Pembahasan}

Pengamatan perkembangan serangan hama $H$. vitessoides pada pertanaman gaharu di HP Carita selama 3 tahun memperlihatkan pola yang relatif tetap, yakni terjadi sepanjang tahun dengan intensitas yang fluktuatif. Serangan berat terutama pada musim kering, yakni antara bulan Juli-September. Pola serangan yang serupa dilaporkan terjadi di Bhutan (Chhetri, 2010), salah satu Negara di kawasan Asia Selatan yang berbatasan dengan China, dan Bangladesh (Chowdhury, 2014). Pola serangan yang lebih tinggi pada musim kemarau daripada musim hujan kemungkinan dipengaruhi oleh aktivitas terbang serangga dewasa pada saat mencari pasangan atau pun mencari tempat bertelur. Pada musim kemarau serangga dewasa dapat lebih aktif melakukan penerbangan karena tidak terganggu curah hujan, sebagaimana pada musim penghujan. Beberapa penelitian menunjukkan terdapat korelasi negatif antara aktivitas terbang ngengat dengan curah hujan (Gharekhani, 2009; Bonsignor \& Manti, 2013). Curah hujan tidak saja secara fisik menjadi faktor pembatas aktivitas terbang ngengat, tetapi turunnya hujan, khususnya yang terjadi di ambang petang, secara tidak langsung juga berkaitan dengan adanya emisi senyawa volatile dari tumbuhan inang yang bersifat repellent (Gharekhani, 2009).

Tingginya serangan hama ulat gaharu pada musim kemarau diduga didukung oleh potensi keberhasilan setiap individu untuk dapat menyelesaikan perkembangan hidupnya hingga menjadi serangga dewasa. Selain tersedia sumber pakan yang cukup untuk memenuhi kebutuhan selama menyelesaikan stadia larva, musim kemarau juga menyediakan seresah dan lantai hutan yang kondusif untuk menginkubasi pupa $H$. vitessoides sampai keluarnya serangga dewasa. Sebaliknya, curah hujan yang tinggi pada musim hujan menyebabkan tanah menjadi sangat lembab dan temperatur tanah turun, sehingga mempengaruhi perkembangan pupa. Uji coba oleh Wen et al. (2016) di laboratorium membuktikan bahwa pada kondisi substrat tanah yang sangat basah (tingkat kejenuhan $>80 \%$ ) larva instar akhir $H$. vitessoides hanya sedikit yang mampu menyelesaikan stadia pupa. 
Kegagalan proses pupasi pada kondisi substrat tanah yang sangat basah juga terjadi pada serangga lain, misalnya Spodoptera exigua, yang dalam proses metamorfosisnya harus melalui stadia pupa di dalam tanah (Zheng et al., 2013).

Kondisi ekologis plot tampaknya berpengaruh terhadap intensitas serangan hama $H$. vitessoides. Tegakan campuran berbagai jenis tanaman yang lebih padat di plot I kemungkinan ikut berperan mengurangi potensi serangan hama dibanding 2 plot lainnya yang lebih terbuka. Hasil penelitian Rahayu dan Maharani (2012) menunjukkan hal tersebut, dimana keragaman jenis tumbuhan diketahui berkorelasi negatif dengan tingkat serangan hama. Karakteristik lokasi dengan keanekaragaman jenis dan kerapatan tegakan yang tinggi diduga mempengaruhi aktivitas terbang serangga dewasa untuk dapat menemukan pohon gaharu yang akan digunakan untuk bertelur. Kasus semacam ini ditemukan Bonsignore dan Manti (2013) pada ngengat jenis Thaumetopoea pityocampa yang merupakan hama pada tanaman pinus, dimana serangga dewasa lebih banyak terbang di kawasan hutan pinus dengan tingkat kepadatan yang rendah.

Menurut Niccoli et al. (2008), keberadaan jenis tumbuhan lain (non host species) juga dapat menjadi faktor penghalang secara kimiawi bagi serangga tertentu untuk menemukan tumbuhan inangnya. Bagi serangga herbivora, senyawa volatile tumbuhan merupakan unsur yang sangat penting untuk dapat mengarahkannya menemukan tumbuhan inang yang tepat untuk bertelur, makan dan kawin (Hussain, 2013; Lu et al., 2014). Percobaan di laboratorium maupun di lapang membuktikan hal tersebut, dimana berbagai jenis serangga betina bereaksi secara spesifik pada senyawa volatile tumbuhan tertentu (Tasin et al., 2009; Pinero \& Dorn, 2009; Anfora et al., 2009). Peran senyawa volatile ini menjadi lebih penting lagi bagi golongan serangga yang termasuk oligofagus seperti $H$. vitessoides karena jenis tumbuhan inangnya sangat terbatas. Oleh sebab itu, pada lingkungan dengan keragaman dan kerapatan jenis tumbuhan yang tinggi seperti pada plot I, intensitas serangan ulat gaharu relatif lebih rendah daripada 2 plot lainnya yang lebih terbuka. Hal ini diduga disebabkan oleh faktor penghalang berupa senyawa volatile dari berbagai jenis tumbuhan lainnya. Menurut Randlkofer et al. (2010), pergerakan kelompok hewan arthropoda secara alami sangat tergantung bagaimana keterkaitan antar senyawa volatile dengan keragaman spesies tumbuhan yang ada.
Tampaknya, ragam aroma senyawa volatile di lingkungan yang sangat tinggi keragaman jenis tumbuhannya menjadi hambatan bagi serangga tertentu untuk mengenali tumbuhan inangnya (Hussain, 2013). Qiao et al. (2012) membuktikan hal tersebut pada ngengat $H$. vitessoides, dimana sintesis senyawa volatile dari daun muda tanaman gaharu jenis $A$. sinensis tidak cukup efektif memikat ngengat di lapang, walaupun di laboratorium terbukti dengan meyakinkan. Qiao et al. (2012) menduga bahwa beragam senyawa volatile di lapangan menjadi faktor pengganggu bagi ngengat betina untuk mengenali inangnya.

Pada penelitian ini diketahui bahwa hama $H$. vitessoides selalu ditemukan di setiap bulan pengamatan di ketiga blok penanaman gaharu di KHDTK Carita yang digunakan sebagai plot pengamatan. Sebagian besar dijumpai sebagai agregasi ulat gaharu. Dilihat dari ukuran tubuh ulat, agregasi ulat gaharu yang ditemukan di masing-masing plot pengamatan terdiri dari bermacam tingkat perkembangan (instar). Ditilik dari siklus hidup $H$. vitessoides sekitar 23,9-46,3 hari untuk menyelesaikan keseluruhan tingkat perkembangan individu dari telur hingga ngengat dewasa (Chen et al., 2011; Agustina, 2012; Emilia, 2013), maka beberapa fakta di atas membuktikan bahwa ngengat ini dapat berkembang dalam beberapa generasi selama satu tahun. Beberapa penulis menyatakan bahwa $H$. vitessoides dapat berkembang sebanyak 7-8 generasi dalam satu musim (Chen et al., 2011; Qiao et al., 2012).

Apabila dilihat dari kecenderungan perkembangan serangan ulat gaharu, maka berdasarkan data intensitas serangan tahunan yang tercatat di Tabel 2, pada tahun kedua (2013) terjadi peningkatan intensitas serangan di semua plot pengamatan. Hal tersebut terlihat dari menurunnya persentase jumlah pohon yang tidak terserang hama (frekuensi serangan 0) dan meningkatnya persentase jumlah pohon dengan frekuensi serangan berulang (frekuensi serangan $\geq 2$ ). Pada tahun ketiga (2014), intensitas serangan relatif konstan seperti tahun kedua (2013), kecuali pada plot I yang sedikit menurun. Selain karena secara sengaja tidak dilakukan tindakan pengendalian di semua plot penelitian, peningkatan kuantitas dan kualitas serangan hama juga mengindikasikan rendahnya potensi pengendali alami hama ini di KHDTK Carita, baik yang bersifat biotik, seperti predator dan patogen maupun yang bersifat abiotik, misalnya faktor iklim. Ketiadaan potensi pengendali alami ini pula yang kemungkinan menjadi penyebab 
semakin merebaknya serangan hama ini di berbagai daerah di Indonesia.

Hasil penelitian ini menegaskan bahwa ulat $H$. vitessoides merupakan hama yang sangat serius dan berbahaya bagi tanaman gaharu. Petani gaharu harus memberikan perhatian dan kewasdaan tinggi mengingat serangan ulat gaharu terjadi sepanjang tahun. Perhatian yang lebih tinggi harus diberikan pada tanaman gaharu di tingkat seedling dan pancang yang sangat rentan terserang dengan melakukan pengawasan dan pemberantasan hama secara berkala.

Upaya pengendalian sebaiknya dilakukan sejak dini pada saat tingkat serangan masih relatif rendah. Pada tahap awal pengendalian harus dilakukan terus menerus mengingat setiap individu serangga betina dewasa mampu berkembangbiak secara masif dengan menelurkan ratusan calon individu baru. Pengendalian yang terus menerus akan dapat menekan perkembangan populasi dan tingkat serangan ulat gaharu. Pengalaman petani gaharu di Desa Ciapus, Bogor, membuktikan hal tersebut. Upaya pengendalian yang terus menerus dilakukan selama 6 bulan berturut-turut pada kebun gaharu seluas 2 ha mampu menurunkan tingkat serangan dari yang semula sangat berat hingga praktis terbebas dari serangan ulat gaharu.

\section{KESIMPULAN DAN SARAN}

\section{A. Kesimpulan}

Serangan ulat daun gaharu di KHDTK Carita terjadi sepanjang tahun dengan pola serangan berfluktuasi. Serangan ulat lebih tinggi terjadi pada musim kemarau. Frekuensi serangan hama ulat $H$. vitessoides pada setiap pohon gaharu yang terserang berkisar 1-4 kali per tahun.

Intensitas serangan ulat gaharu cenderung lebih tinggi terjadi pada tanaman gaharu tingkat seedling. Pertanaman gaharu pada lahan yang lebih terbuka dengan tingkat kerapatan tegakan dan tumbuhan bawah yang lebih rendah cenderung lebih rentan terserang hama ulat gaharu.

Tidak ada blok pertanaman gaharu KHDTK Carita yang terbebas dari serangan ulat $H$. vitessoides. Intensitas serangan terendah terjadi pada blok I dengan kerapatan vegetasi yang lebih tinggi (tegakan $=6.875$ batang per ha dan tumbuhan bawah $=12.950$ individu per ha), dimana pohon gaharu yang tidak terserang hama lebih tinggi dibanding plot lainnya $(22,2 \%$ berbanding $4,8 \%$ dan $2,2 \%$ ) dan pohon yang mengalami serangan berulang jumlahnya lebih rendah (36,2\% berbanding $66,7 \%$ dan $74,1 \%)$.

\section{B. Saran}

Kegiatan pengendalian hama ulat gaharu perlu memperhatikan dinamika populasi hama di lapangan agar upaya pengendalian dapat dilakukan secara lebih efektif dan efisien. Pengendalian sebaiknya dilakukan secara terusmenerus terutama pada saat tingkat serangan masih relatif rendah, yakni menjelang musim hujan dan pada akhir musim hujan yang ditandai dengan jumlah hari hujan $(\mathrm{HH})$ relatif rendah $(<$ 10 hari per bulan) dan curah hujan $(\mathrm{CH})$ kurang dari $100 \mathrm{~mm}$.

\section{UCAPAN TERIMA KASIH}

Penelitian ini dibiayai melalui dana APBN dari DIPA Pusat Penelitian dan Pengembangan Hutan (P3H) tahun anggaran 2012 sampai dengan 2014. Penulis menyampaikan ucapan terima kasih kepada jajaran manajemen $\mathrm{P} 3 \mathrm{H}$ yang telah memfasilitasi pendanaan dan membantu kelancaran pelaksanaan penelitian. Ucapan terima kasih juga penulis sampaikan kepada teknisi dan petugas lapangan KHDTK Carita, khususnya Bapak Atep, Masroji dan Anwar yang banyak membantu dalam pengumpulan data di lapang.

\section{DAFTAR PUSTAKA}

Agustina, T. (2012). Biologi hama Heortia sp. (Lepidoptera: Crambidae) pada tanaman mahkota dewa (Phaleria macrocarpa) di laboratorium. Skripsi. Jurusan Proteksi Tanaman, Fakultas Pertanian, Universitas Lampung.

Anfora, G., Tasin, M., de Cristofaro, A.D., Ioriatti, C., \& Lucchi, A. (2009). Synthetic grape volatiles attract mated Lobesia botrana females in laboratory and field bioassays. J. of Chemical Ecology, 35, 1054-1062.

Bonsignore, C.P., \& Manti, F. (2013). Influence of habitat and climate on the capture of male pine processionary moths. Bulletin of Insectology, 66(1), 27-34.

Chen, Z.Y., Li, D.W., Wang, L., Li, Y.Z., Huang, X.R., \& Qin, C.S. (2011). Studies on biological characteristics of Heortia vitessoides Moore on Aquilaria sinensis. China Plant Protection 
2011-11. Abstract. http://en.cnki.com.cn/ A r i c l e e n / C J F D T O T A L ZBJS201111003.htm.

Chhetri, D.B. (2010). Heortia vitessoides: a serious pest of agar tree. RNR-RDC News Letter Department of Forest and Park Service, Yusipang Rigpel, 13, 10.

Chowdhury, M. (2014). Production of agarwood through aeration method into the agar tree. MS Thesis. Department of Farm Power and Machinery, Bangladesh Agricultural University, Mymensingh, Bangladesh.

Dhawan, A.K. \& Peshin, R. (2009). Integrated pest management: concept, opportunities and challenges. In Peshin \& Dhawan (eds.): Integrated pest management: innovationdevelopment process. Volume1. Springer.Pp 51-82.

Emilia, H. (2013). Biologi Heortia vitessoides Moore (Lepidoptera: Crambidae) pada tanaman mahkota dewa (Phaleria macrocarpa (scheff.). Boerl.). Skripsi. Departemen Proteksi Tanaman, Fakultas Pertanian, IPB.

Gharekhani, G. (2009). Modeling population dynamics and dispersion of codling moth Cydia pomonella L. (Lepidoptera: Tortricidae). Dissertation. Faculty of Agricultural Science, Hohenheim University, Stuttgart, Germany.

Hariri, A.M. (2012). Mortalitas penghambatan makan dan pertumbuhan hama daun gaharu Heortia vitessoides Moore oleh ekstrak buah Brucea javanica (L.) Merr. J. HPT Tropika, 12(2), 119128.

Hariri, A.M., \& Indriyati. (2011). Karakteristik hama pemakan daun mahkota dewa (Phaleria macrocarpa [Scheff.] Boerl.). Ginting, C. \& Hendri, J. eds. Prosiding Seminar Hasil-hasil Penelitian dan Pengabdian Kepada Masyarakat. Lembaga Penelitian Universitas Lampung, I-64-I-70.

Lestari, F. \& Darwiati, W. (2014). Uji efikasi ekstrak daun dan biji dari tanaman suren, mimba, dan sirsak terhadap mortalitas hama ulat gaharu. $J$. Penelitian Hutan Tanaman, 11(3), 165-172.

Lestari, F. \& Suryanto, E. (2012). Efikasi Basillus thuringiensis terhadap hama ulat daun gaharu Heortia vitessoides. J. Penelitian Hutan Tanaman, 9(4), 227-232.

Hussain, A. (2013). The effect of non-host plant volatiles on the reproductive behavior of the Egyption cotton leafworm, Spodoptera littoralis. Master's Thesis. Swedish University of Agricultural Science.
Irianto, R.S.B., Santoso, E., Turjaman, M., \& Sitepu, I.R. (2011). Pests that attack gaharu yielding plants. Turjaman, M. (ed.): Development of gaharu production technology, a forest community based empowerment. Procceeding of Gaharu Workshop, November 5, 2010, Bogor: Pusat Penelitian dan Pengembangan Hutan dan Konservasi Alam, 89-93.

Lu, P.F., Qiao, H.L., Xu, Z.C., Cheng, J., Zong, S.X., \& Luo, Y.Q. (2014). Comparative analysis of peach and pear fruit volatiles attractive to the oriental fruit moth, Cydia molesta. J. of Plant Interactions, 9(1), 388-395.

Mohd Masri, S., Rosliza, J., Mohd Fahimee, J., Muhamad Radzali, M., Azman, R., Ong, S.P., \& Mohd Farid, A. (2014). Heortia vitessoides, major pest of mahkota dewa (Phaleria macrocarpa) in Taman Tropika Kenyir (TTK), Terengganu. Conference Paper on Agrobiodiversity and Agroenvironment Symposium (A-BES) 2014: "Sustainable Agro-Ecosystem for Rapid and High Impact Development", 15 18 September 2014, Kuching, Sarawak, Malaysia. Abstract.

Niccoli, A., Panzavolta, T., Marziali, L., Sabbatini Peveriari, G., Tellini Florenzano, G., \& Tiberi, R. (2008). Further studies on the role of monoterpenes in pine host selection and oviposition of Thaumetopoea pityocampa. Phytoparasitica, 36, 313-321.

Orr, D. (2009). Biological control and integrated pest management. In Peshin \& Dhawan (eds.): Integrated pest management: innovationdevelopment process. Volume 1. Springer. Pp. 207-239.

Pinero, J.C., \& Dorn, S. (2009). Response of female oriental fruit moth to volatiles from apple and peach trees at three phonological stages. Entomologia Experimentalis et Applicata, $131,67-74$

Qiao, H.L., Lu, P.F., Chen, J., Ma, W.S., Qin, R.M., \& Li, X.M. (2012). Antennal and behavioural responses of Heortia vitessoides females to host plant volatiles of Aquilaria sinensis. Entomologia Experimentalis et Applicata, 143(3), 269-279.

Rahayu, A.D., \& Maharani, D. (2012). Parameter ekologi serangan hama ulat daun (Heortia vitessoides Moore) pada tanaman gaharu (Gyrinops versteegii (Gilg) Domke) di Pulau Lombok. Jurnal Penelitian Hutan dan Konservasi Alam, 9(4), 385-393.

Randlkofer, B., Obermaier, E., Hilker, M., \& Meiners, T. (2010). Vegetation complexity -the influence of plant species diversity and plant structures on plant chemical complexity and 
arthropods. Basic and Applied Ecology, 5, 383395.

Saikia, M. \& Shrivastava, K. (2015). Biological control of Heortia vitessoides Moore, the most serious insect defoliator of Aquilaria malaccensis Lamk., a commercially important tree species of Northeast India. Annals of Biological Research, 6(5), 26-32.

Samsoedin, I., Heriyanto, N.M., \& Subiandono, E. (2010). Struktur dan komposisi jenis tumbuhan pamah di kawasan hutan dengan tujuan khusus (KHDTK) Carita, Provinsi Banten. $J$. Penelitian Hutan dan Konservasi Alam, 7(2), 139-148.

Tasin, M., Backman, A.C., Anforal, G., Carlin, S., Ioriatti, C., \& Witzgall, P. (2009) Attraction of female grapevine moth to common and specific olfactory cues of 2 host plants. Chemical Sense, 35, 57-64.

Wen, Y., Jin, X., Zhu, C., Chen, X., Ma, T., Zhang, S., Zhang, Y., Zeng, S., Chen, X., Sun, Z., Wen, X., $\&$ Wang, C. (2016). Effect of substrate type and moisture on pupation and emergence of Heortia vitessoides (Lepidoptera: Crambidae): Choice and no-choice studies. J. Insect Behav. 29, 473-489. DOI 10.1007/s10905-016-95722

Zheng, X.L., Wang, P., Lei, C.L., Lu, W., Xian, Z.H., \& Wang, X.P. (2013). Effect of soil moisture on overwintering pupae in Spodoptera exigua (Lepidoptera: Noctuidae). Appl. Entomol. Zool.48(3), 365-371. 